\title{
Senecio scapioides (Compositae: Senecioneae: Senecioniinae): a new species from the Departamento de Boyacá, in Andean Colombia
}

\author{
José Aguilar-Cano ${ }^{1}$ (D) \& D. J. Nicholas Hind ${ }^{2}$
}

Summary. Routine use of the virtual herbarium of the collections in COL (Instituto de Ciencias Naturales de la Universidad Nacional de Colombia) revealed the presence of an as yet undescribed species of Senecio amongst the material of Senecio adglacialis and S. leucanthemoides. Following subsequent herbarium studies and fieldwork, Senecio scapioides (Compositae: Senecioneae: Senecioniinae), from the Departamento de Boyacá, in Andean Colombia, was recognised and is described and illustrated; it is compared with S. adglacialis and S. leucanthemoides. Notes on its distribution and habitat, conservation status, phenology, and etymology are also provided, and the distribution of the three species mapped.

Resumen. Revisiones rutinarias del herbario virtual de las colecciones en COL (Instituto de Ciencias Naturales de la Universidad Nacional de Colombia) reveló la presencia de una especie aún no descrita de Senecio entre el material de Senecio adglacialis y $S$. leucanthemoides. Como resultado del trabajo de herbario y campo subsiguientes, Senecio scapioides (Compositae: Senecioneae: Senecioniinae), del Departamento de Boyacá, en los andes colombianos, fue reconocida e ilustrada; la nueva especie se compara con S. adglacialis y S. leucanthemoides. Adicionalmente se discute su distribución y hábitat, estado de conservación, fenología y etimología, así como el mapa de distribución geográfica de las tres especies.

Key Words. Asteraceae, checklist, digitisation, Flora of Colombia.

\section{Introduction}

In 2015, one of the authors (DJNH) reassessed the status of the Compositae in published Floras, checklists and available related databases. During that exercise, the available database for the checklist of the Colombian Flora (Bernal et al. 2015) was reassessed for its completeness (of both genera and species), for the Compositae. At that time, 230 genera (together with 7 splits from Vernonia Schreb.), including 1274 species, this represented 523 endemic species (41.1\% of the total of Compositae), and equivalent to $5.6 \%$ of the Flora's angiosperm total. However, a significant number of taxa (both genera and species) were missing from the database; this re-assessment was put on hold until mid-2017. Whilst the number of genera remains the same (with some added and others deleted), the current estimates are 1260 species (excluding purely cultivated species), including 582 endemics $(46.3 \%)$.

In 2016, the Royal Botanic Gardens, Kew, became a partner in a joint programme, Colombia Bio (Colombia BIO 2016), established by ColCiencias (the Colombian Administrative Department of Science, Technology and Innovation), and aimed at increasing knowledge of Colombia's biodiversity. This partnership involves the Instituto de Investigación de Recursos Biológicos Alexander von Humboldt (FMB = Herbario Federico Medem Bogotá), and the Universidad Pedagógica y Technológia de Colombia; Kew's involvement is funded in part by the British Council (via BEIS = Department for Business, Energy \& Industrial Strategy, UK). As a subset of Colombia $\mathrm{BIO}$, Boyacá Bio is a regional programme which Kew has become directly involved with. The intention is to provide checklists of some of the more important families of flowering plants (Araceae, Leguminosae, Myrtaceae) where Kew has some expertise, and often in collaboration with Colombian researchers, for the Departamento de Boyacá. The experience of one author (DJNH) in creating annotated systematic checklists (see Hind 2011, for an unpublished version of one for Bolivia), was then used to create a similar style of preliminary checklist of the Compositae for the Departamento de Boyacá, Colombia, en route to a full draft list of the Compositae of Colombia,

\footnotetext{
Accepted for publication 4 March 2020. Published online 24 August 2020

1 Instituto de Investigación de Recursos Biológicos Alexander von Humboldt, Herbario FMB, Carrera 8 \# 15-08, Claustro de San Agustín, Villa de Leyva, Colombia. e-mail: jaguilar@humboldt.org.co

2 Herbarium, Royal Botanic Gardens, Kew, Richmond, Surrey, TW9 3AE, UK. e-mail: n.hind@kew.org
} 
supplementing the published Catálogo (Bernal et al. 2016a, b).

Whilst the second author (DJNH) constructed the Compositae checklist for the Departamento, constant checks were made against the virtual herbarium of the Instituto de Ciencias Naturales de la Universidad Nacional de Colombia (= COL). These were primarily concerned with a visual confirmation that the determinations of the material were correct, as well as supplying supplementary information to be used in the checklist (e.g. altitude of collections, habit and habitat, and flowering time). At present, following the second author's listing, there are 23 native or native and naturalised genera from the tribe Senecioneae present in Colombia. The two largest genera are the shrubby Monticalia C.Jeffrey (45 spp. - c.f. no accepted species in Avila et al. 2016; 32 spp. endemic) and lianescent Pentacalia Cass. (46 spp. - cf. 103 spp. in Bernal et al. 2016a, b; 34 spp. endemic); Senecio L. (mostly perennial stoloniferous herbs in Colombia) is the third largest with 37 spp. recorded to date (compared to 43 spp. in Avila et al. 2016; 24 spp. endemic), of which an estimated 24 spp. are considered endemic to the country. Within Boyacá only 15 genera have been recorded, although the same genera are foremost, with Monticalia the largest (19 spp., 13 spp. endemic) and Pentacalia with only 9 spp. (6 spp. endemic), except that Senecio is the second largest (17 spp.), of which 11 spp. are endemic.

However, it was during that process that it became clear that within Senecio some imaged collections did not belong to the taxa to which they had been determined. Most of the senecios in Boyacá are high altitude species $(3,000-5,000 \mathrm{~m}$, rarely down to 2,000 $\mathrm{m}$ ) and, excluding the weedy $S$. vulgaris $\mathrm{L}$. (which is only present in its discoid form in Colombia - e.g. Cuatrecasas 13658, Díaz-Piedrahita et al. 958, Knoth 3379, Velasco 184), $75 \%$ of them possess radiate capitula, together with one variety of $S$. comosus Sch.Bip.; half of the radiate species have yellow ray limbs, the others purple or carmine-coloured. All of the discoid-headed taxa possess yellow corollas. Material determined as S. leucanthemoides Cuatrec., other than the type collection, Cuatrecasas et al. 12050 (and the contemporaneous Cuatrecasas et al. 12055), was clearly not conspecific. In addition, material determined as S. adglacialis Cuatrec. was clearly not that species, but appeared identical to that mis-determined under $S$. leucanthemoides together with one additional sheet under the easily-recognised S. formosus Kunth. This unmatched material is of a distinctive rhizomatous perennial herb with entire to sparsely serrate sessile leaves and solitary, scapiform radiate capitula, with yellow ray limbs.

The two authors of the present paper made contact, via Dr Steven Sylvester (now Associate Professor at NF, Nanjing Forestry University), during
November 2017, and the first author examined the errant herbarium material in COL, as well as the material in FMB, securing a loan of material from FMB to COL, and undertaking fieldwork to check the localities highlighted by the material seen in COL virtual herbarium. It became clear that this material is indeed of a species of Senecio not previously recognised for Colombia and it is formally described below.

\section{Description}

Senecio scapioides Aguilar-Cano \& D.J.N.Hind, sp. nov. Type: Colombia. Departamento de Boyacá: Municipio de Arcabuco, Cordillera Oriental, Vereda Rupavita, Parque Natural Regional Paramo del Valle, $5^{\circ} 44^{\prime} 45^{\prime \prime} \mathrm{N}$, 7322'7"W, 3696 m, 18 Nov. 2017 (fl.), J. Aguilar-Cano 4434 (holotype FMB, isotype K).

http://www.ipni.org/urn:lsid:ipni.org:names:77206330-1

Rhizomatous, single-stemmed perennial herbs up $45 \mathrm{~cm}$ tall; basal stem creeping, decumbent, thin-woody, 1.5 $3.5 \mathrm{~mm}$ diam., unbranched. Inflorescence scapiform, erect, $15-37 \mathrm{~cm}$ tall, purple, indumentum densely arachnoid and sericeous, white, covering stems, abaxial leaf surface and involucre, together with glandular, simple multicellular-uniseriate, whitish hyaline trichomes $1.4-2.8 \mathrm{~mm}$ long, composed of $22-36$ (42) short-oblong cells, these becoming gradually smaller towards apex, ending in a rounded cell. Basal leaves 15 - 20 together in a loose rosette, these present at anthesis, leaf blade narrowly oblanceolate-oblong to oblanceolate-oblong, $22-45(-50) \times 3-6 \mathrm{~mm}$, sessile, lamina base abruptly attenuate and not dilated at node, herbaceous, pubescent especially along margins, on apex and veins, abaxially whitish green to purple, with an arachnoid and sericeous indumentum, adaxially green, midrib purple, margins entire to obscurely dentate and moderately revolute, apex acute-apiculate; cauline leaves $7-15$, dissimilar to basal leaves, sparser and gradually smaller towards stem apex, sessile, base dilated but not auriculate, blade narrowly oblong-lanceolate or linear-lanceolate, 16 $28 \times 3-5 \mathrm{~mm}$, herbaceous, adaxially green, densely sericeous-pubescent, abaxially completely purple and indumentum densely arachnoid and pubescent, midrib purple, margins dentate and strongly revolute, apex acute-apiculate. Capitula heterogamous and radiate, solitary and nodding; involucre campanulate, $10-$ $33 \times 16-43 \mathrm{~mm}$, involucre closely subtended by a calyculus, calycular bracts $10-12$, linear-lanceolate, 13 $-13 \times 0.9-1.3 \mathrm{~mm}$, herbaceous, green and apically purplish, densely arachnoid and sericeous, apex acuminate with a tuft of short glandular, unicellular trichomes; phyllaries 15, uniseriate, linear-lanceolate, $14-17 \times 1.3-2.5 \mathrm{~mm}$, herbaceous, green, apically purplish, indumentum arachnoid and sericeous, 
margins scarious, $0.4-0.8 \mathrm{~mm}$ wide, often fimbriate, apex acuminate with a tuft of short, glandular, unicellular trichomes; receptacle weakly convex, 5 $6 \times 9-10 \mathrm{~mm}$, surface honeycombed. Ray florets $16-$ 18 , female and fertile, ray limb elliptic-oblong, 15.1 $16.2 \times 6.2-7.2 \mathrm{~mm}$, yellow, glabrate, apex finely 3dentate, 8-veined, corolla tube yellow, cylindrical, 5.9 $6.4 \mathrm{~mm}$ long, densely pubescent towards apex with simple, glandular, multicellular uniseriate trichomes, $0.3-0.6 \mathrm{~mm}$ long; staminodes present; style yellow, 5.4 $-8.5 \mathrm{~mm}$ long, base dilated, style arms with marginal stigmatic lines, $1.3-2.1 \mathrm{~mm}$ long, apices truncate, covered by regularly distributed papillae. Achenes ovate, $1.5-1.9 \times 0.5-0.8 \mathrm{~mm}$, covered with short, glandular, unicellular trichomes; carpopodium symmetrical in a broad ring, $0.2 \mathrm{~mm}$ diam.; pappus setae numerous, unequal, biseriate, 4.5 - $7.3 \mathrm{~mm}$ long, barbellate, deciduous, white. Disc florets numerous, 90 - 200, hermaphrodite, fertile; corollas bright yellow at anthesis (brownish post anthesis), 8.2 - $9.9 \mathrm{~mm}$ long, limb funnel-shaped, tube $3.0-3.6 \mathrm{~mm}$ long, glabrate, throat $4.4-5.4 \times 1.1-1.5 \mathrm{~mm}$, 5-lobed, triangularovate, $0.9-1.0 \times 0.5-0.6 \mathrm{~mm}$, abaxially thickened and adaxially with a tuft of papillae; anthers barely exserted, $2.8-3.0 \times 0.2-0.4 \mathrm{~mm}$, apical anther appendages lanceolate, anther bases calcarate, anther collars $0.8-1.0 \mathrm{~mm}$ long, in front view $0.2-0.3 \mathrm{~mm}$ and $0.1-0.2 \mathrm{~mm}$ wide (proximal and distal measurements respectively), in side view distally flattened and proximally elongate, balusterform, composed of $8-9$ layers of rectangular cells; filaments flat, inserted below apex of corolla tube and adnate throughout; style yellow, 7.9 - $10.6 \mathrm{~mm}$ long, glabrous, style arms $1.7-2.2 \mathrm{~mm}$ long, with marginal stigmatic lines, apices sub-truncate to obtuse with a tuft of irregularly distributed papillae, longer papillae surrounding apex and shorter papillae covering whole surface of apex. Achenes cylindrical, $1.7-2.9 \times 0.5-0.8 \mathrm{~mm}$, covered with short, glandular, unicellular setulae; carpopodium a symmetrical broad ring, $0.2-0.3 \mathrm{~mm}$ in diam.; pappus setae numerous, biseriate, unequal, $6.2-9.5 \mathrm{~mm}$ long, barbellate, deciduous, white.

RECOGNITION. In habit, leaf shape and yellow radiate capitula Senecio scapioides resembles $S$. adglacialis but the new species differs in having a densely arachnoid indumentum and in being sericeous pubescent on its stems, abaxial leaf surface and involucre (vs sparsely arachnoid and sericeous pubescent), generally longer glandular trichomes $(1.2-2.5 \mathrm{~mm}$ long vs 0.5 - $1.7 \mathrm{~mm}$ long), possessing solitary capitula (vs inflorescences densely subcorymbiform, 3 - 5-headed, very rarely singleheaded on dwarf specimens, e.g. van der Hammen 1317), an involucre of fewer phyllaries (15 vs 20) and fewer ray florets (16 - 18 vs 24). (Figs $1,2 \&$ 3), (Table 1).
DISTRIBUTION AND HABITAT. Senecio scapioides occurs in high grass páramos up to the lower limit of the superpáramo, at elevations of 3450 - $4053 \mathrm{~m}$, throughout the north Cordillera Oriental of Colombia, including the páramo complexes of La Rusia, Iguaque-Merchan, Pisba and Tota-BijagualMamapacha in the Department of Boyacá, and the complex of Chingaza in the Department of Cundinamarca, Colombia (Map 1). The species is a solitary terrestrial plant occurring as scattered individuals with low population density on the summits of mountains and on plateaus dominated by grass-stem rosette plant communities of Calamagrostis effusa (Kunth) Steud., Chusquea tessellata Munro (Poaceae) and Espeletia barclayana Cuatrec. (Compositae) (Fig. 3A).

SPECIMENS EXAMINED. COLOMBIA. Boyacá: Municipio de Arcabuco, Cordillera Oriental, Vereda Rupavita, Parque Natural Regional Paramo del Valle, 5 $44^{\prime} 45^{\prime \prime} \mathrm{N}$, $73^{\circ} 22^{\prime} 7^{\prime \prime W}, 3696$ m, 18 Nov. 2017 (fl.), J. Aguilar-Cano 4434 (holotype FMB, isotype K); Municipio de Belen, Complejo Guantiva-La Rusia, parte alta de la montana, cerca al Boqueron El Consuelo, $6^{\circ} 4^{\prime} 8.3^{\prime \prime} \mathrm{N}$, 7257'7.2"W, 4053 m, 23 Nov. 2017, M. Diazgranados 4443 (COL!, FMB!, K!); Municipio de Duitama, Santa Rosa de Viterbo-Duitama, paramo Pan de Azucar, near the road to El Carmen $\left[5^{\circ} 54^{\prime} 1.56^{\prime \prime} \mathrm{N}\right.$, $73^{\circ} 3^{\prime 20.03 " W], ~} 3450$ m, 30 Nov. 1998, D. Stancik 1490 (COL-422996!; FMB-36140!); Municipio de Mongua, Vereda Mongui, alrededores y parte alta del sector Laguna Negra. Parque Natural Regional SiscunsiOceta, 541'22.8186"N, 7247'20.8032"W, 3832 m, 29 Nov. 2017, M. Diazgranados 4532 (COL!, FMB!, K!); Municipio de Pesca, Vereda Butaga, Páramo de La Cortadera, Mata Blanca, [5 $31^{\prime} 21^{\prime \prime N}, 73^{\circ} 7^{\prime} 48^{\prime \prime} \mathrm{W}$, 3750 m, 16 Jan. 1982, Matilde Bejarano 92 (COL-242620!); Municipio de Toca, Páramo Cortadero, boundary with Páramo Siachoque. $5^{\circ} 30^{\prime} \mathrm{N}, 73^{\circ} 15^{\prime} \mathrm{W}, 3650 \mathrm{~m}, 14$ Nov. 1998, D. Stancik 1380 (COL-421010!; FMB37827!); Municipio Socotá, Páramo Pisba, Alto de Cardon. [6 $\left.3^{\prime} 45^{\prime \prime} \mathrm{N}, 72^{\circ} 36^{\prime} 2^{\prime \prime} \mathrm{W}\right], 3540 \mathrm{~m}, 11$ Feb. 1999, D. Stancik 2317 (COL-430122!; FMB38144!). Cundinamarca: Municipio de Fomeque, Páramo de Chingaza, cordilleras vecinas a la laguna y límite con el departamento del Meta [4 $31^{\circ} 15^{\prime \prime N}$, $\left.73^{\circ} 42^{\prime} 55^{\prime \prime W}\right], 3200-3640$ m, 1 Nov. 1966, G. Huertas E L. Camargo 6587 (COL-117236!, COL-205612!); Municipio de Fomeque, Parque Nacional de Chingaza, orilla del camino a San Juanito, pasando el

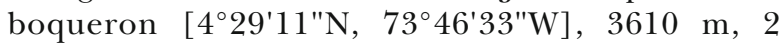
Dec. 1981, P. Franco 843 (COL-231859!).

CONSERVATION STATUS. Senecio scapioides is endemic to Colombia, occurring in the Andean páramo, throughout the northern Cordillera Oriental in the Departments of Boyacá and Cundinamarca. The estimated extent of occurrence $\left(5989 \mathrm{~km}^{2}\right)$ is almost within the threshold for Endangered in criterion B1 and its area 


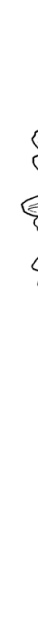

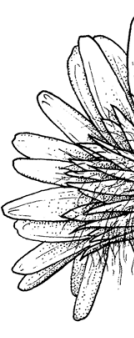

章
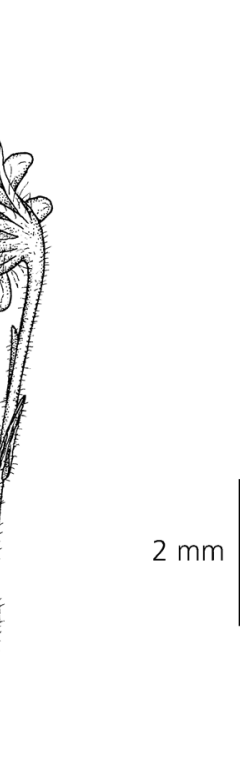

M
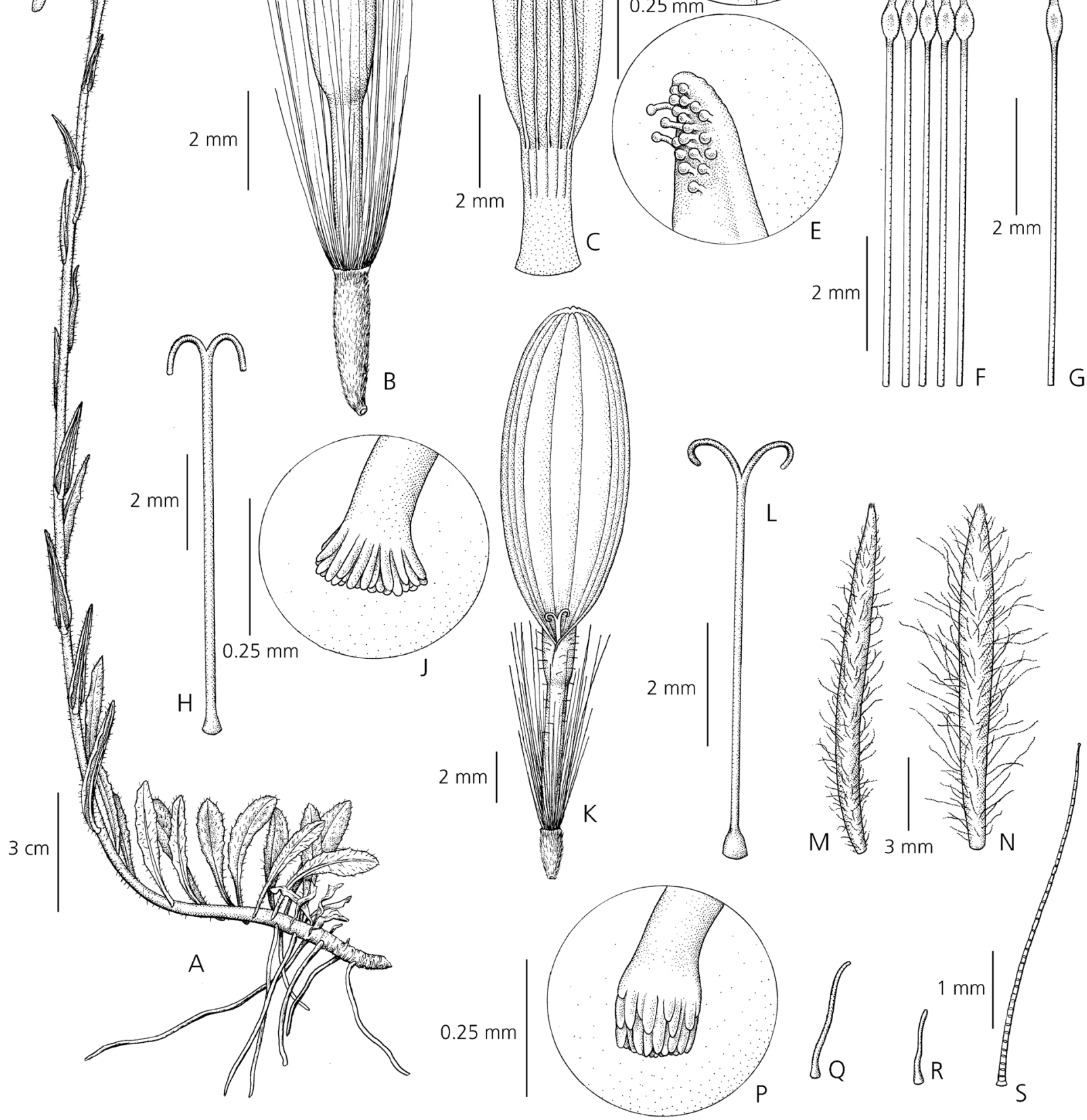

Fig. 1. Senecio scapioides. A habit; $B$ disc floret; $C$ disc floret corolla opened out showing stamen arrangement; $D$ adaxial surface of apex of disc floret corolla lobe; $\mathrm{E}$ abaxial surface of apex of disc floret corolla lobe; $\mathrm{F}$ anther cylinder opened out; $\mathrm{G}$ stamen; $\mathrm{H}$ disc floret style; J apex of disc floret style arm showing the truncate apex with a tuft of irregularly distributed papillae; $\mathrm{K}$ ray floret; $\mathbf{L}$ ray floret style; M calycular bract; N phyllary; P apex of ray floret style arm with apices truncate covered by regularly distributed papillae; Q unicellular trichome from a calycular bract; R unicellular trichome from achene; S multicellular uniseriate trichome from phyllary. All from Aguilar-Cano 4434 (holotype FMB). DRAWN BY GUSTAVO SURLO. 

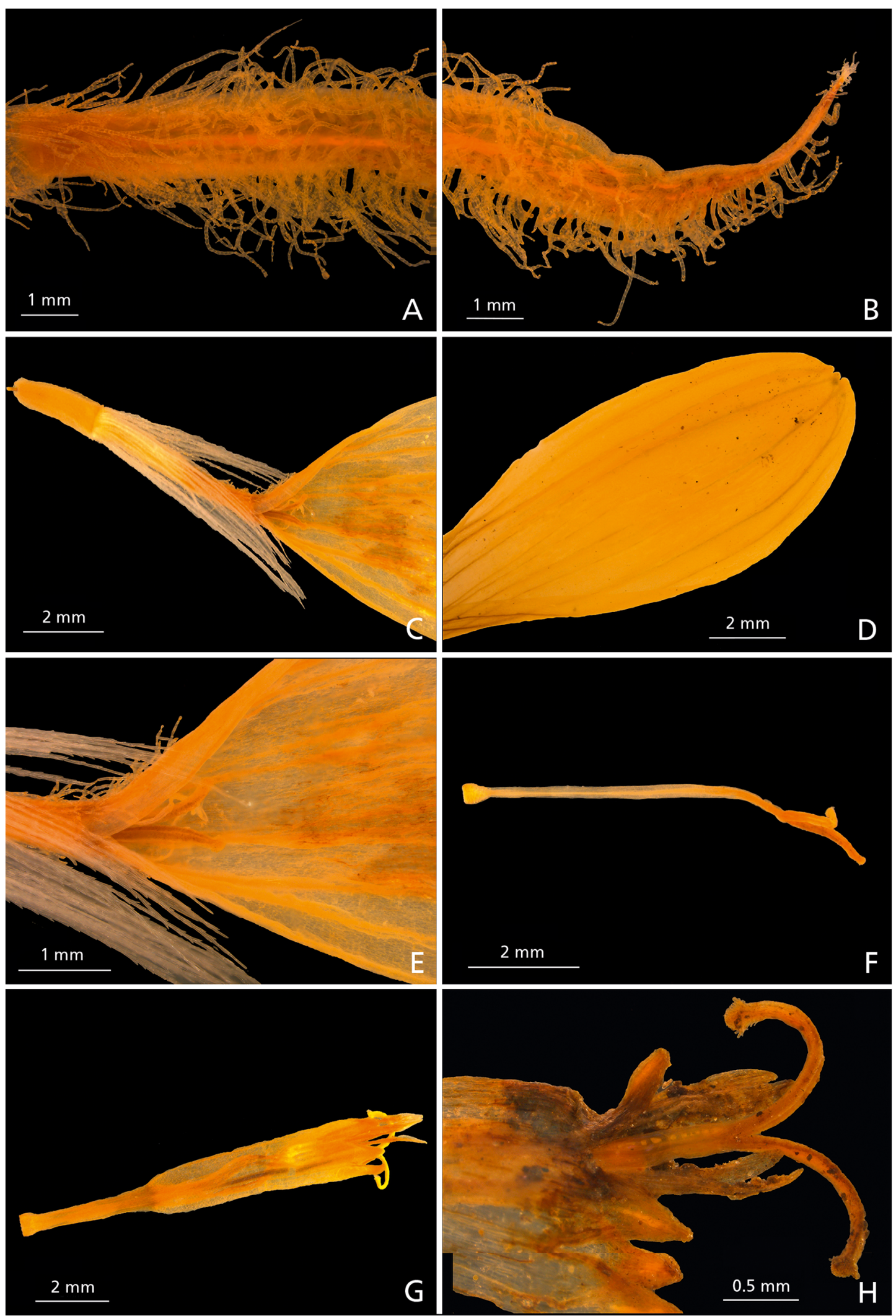

Fig. 2. Senecio scapioides. A phyllary base; B phyllary apex; C ray floret; D ray floret limb; E detail of upper part of corolla tube and base of ray limb; F ray floret style; $\mathrm{G}$ disc floret corolla; $\mathrm{H}$ apex of mature disc floret. All from M. Diazgranados 4443 (K). 

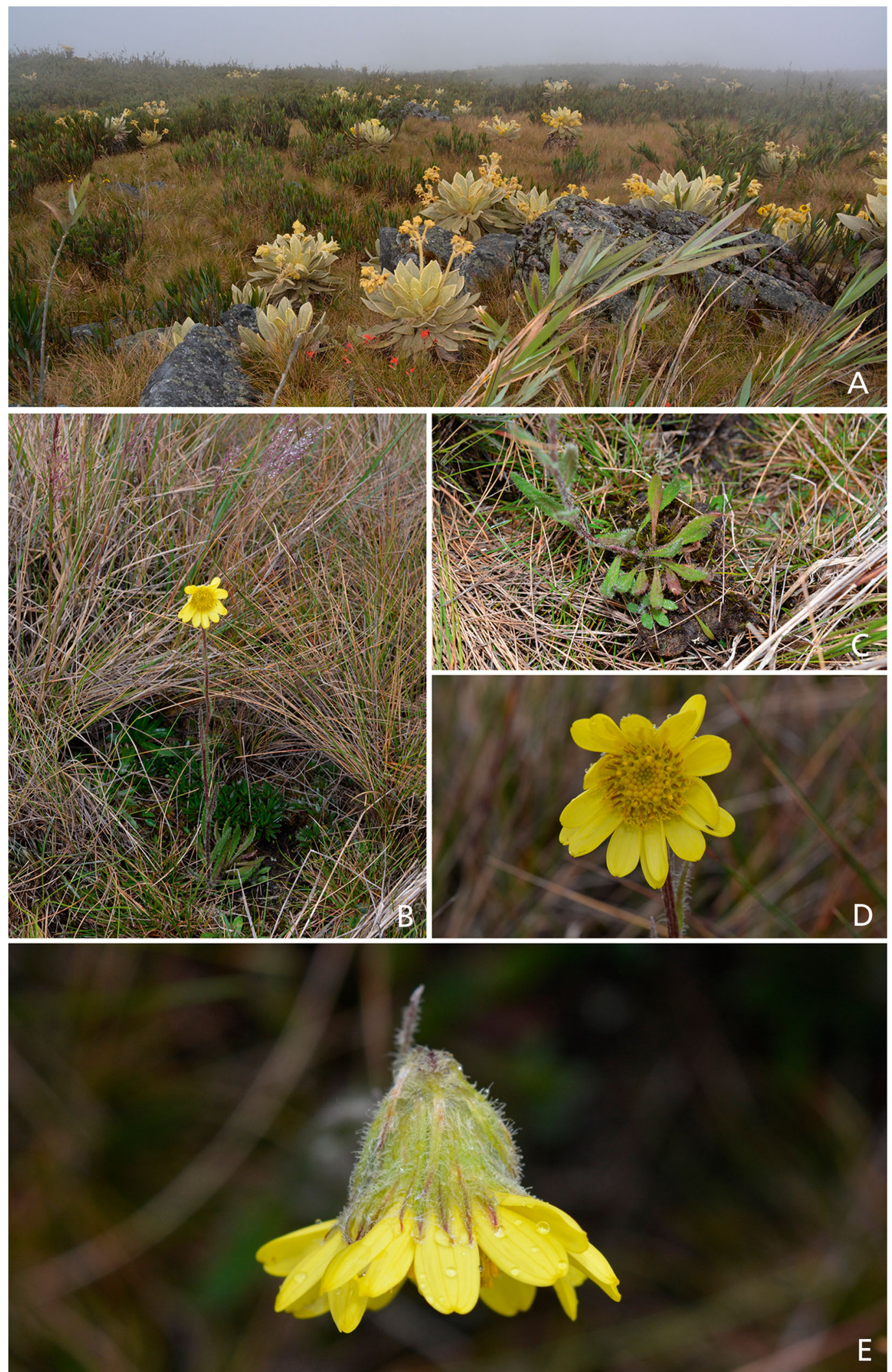

Fig. 3. Senecio scapioides at the type locality. A habitat; B habit; C basal part of stem and basal leaves; D top view of capitulum; E lateral view of capitulum. All from Aguilar-Cano 4434. PHOTOS: JOSÉ AGUILAR-CANO. 


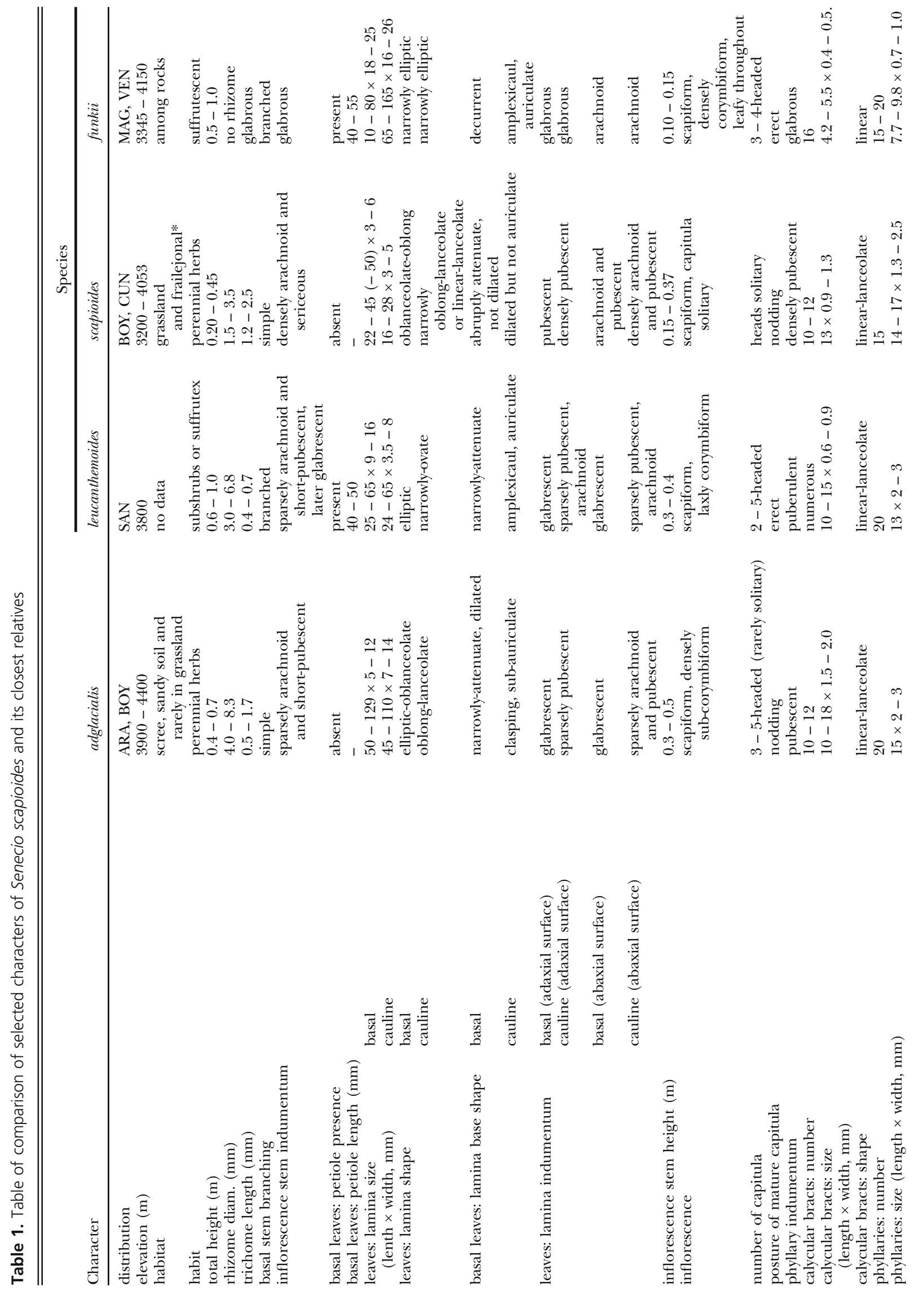




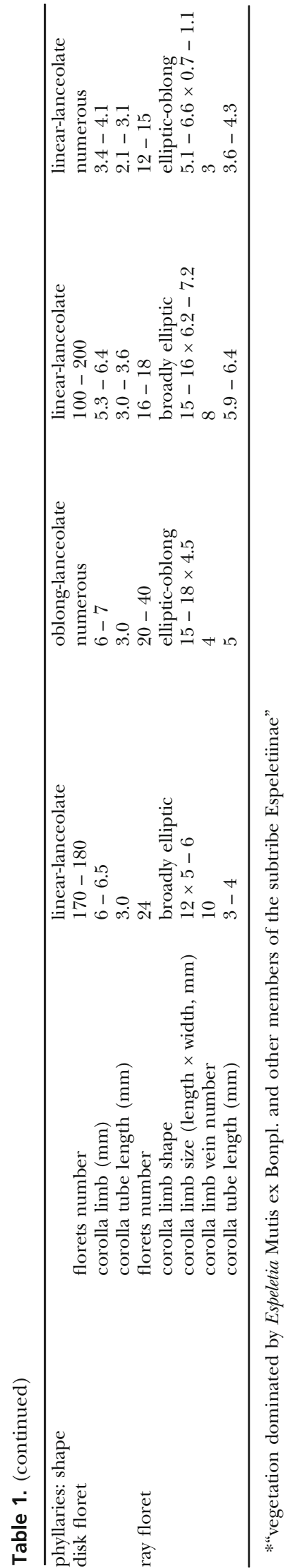

of occupancy is $\left(348 \mathrm{~km}^{2}\right)$ within the threshold for Endangered in criterion B2. The number and size of the populations is not well-known, and the species could not be accurately assessed based on its population size and decline. Nevertheless, the modern threats to habitat of livestock grazing and frequent fires, as well as climate warming and drying in the northern Andes (Vásquez et al. 2015; IPCC 2014), and more than a third of the Páramos de Boyacá now destroyed, mainly due to the introduction of grasslands and crops (Moreno et al. 2016), mean that the species habitat is in continuous decline. Therefore, following the criteria established by the IUCN (2013), Senecio scapioides is at present assessed as Endangered [EN B2 ab (iii)] mainly based on its distribution range. Research is urgently needed to establish the current population size of this new species, as well as to improve the understanding of plant diversity of Compositae in the Andean páramo. PHENOLOGY. Flowering and fruiting simultaneously between November and January.

ETYMOLOGY. The specific epithet derives from the Latin scapus (scape) and -oides (like) and alludes to the scapiform inflorescence of the species.

DISCUSSION. A comparison of the material has shown that Senecio scapioides superficially matches that of $S$. adglacialis Cuatrec. and S. leucanthemoides Cuatrec., together forming a close morphological and geographical group within the senecionoid complex (subtribe Senecioninae s.str.) (Nordenstam et al. 2009) of specialised herbs or suffrutices exclusively adapted to the high páramos of the north Colombian Cordillera Oriental (Map 1). The three species are morphologically characterised by the presence of stems with creeping rhizomes, basal leaves forming a loose rosette, the inflorescence scapiform (Fig. 1A, 3B, $\mathrm{C})$, yellow radiate capitula similar in size and shape (Fig. 3D, E), and staminodes present in the fertile ray florets (Fig. 2E).

Although most of the collections studied of the new species have been previously identified as Senecio leucanthemoides and/or S. adglacialis, this is understandable, because both species have yellow radiate capitula and grow in areas of páramo (Fig. 3). Both J. Cuatrecasas and S. Díaz-Piedrahita, renowned American synantherologists, saw material of the undescribed species but did not describe it.

Senecio adglacialis does not grow sympatrically with $S$. scapioides, since no material of the new species has been found from the superpáramo vegetation of the Sierra Nevada del Cocuy (Map 1). This Sierra has a high percentage of endemics within the Colombian Cordillera Oriental and several senecios are endemic to the Sierra (e.g. S. cocuyanus Cuatrec., S. supremus Cuatrec. and S. pascuiandinus Cuatrec.) (Cleef 1981; Miranda-Esquivel et al. 2002). Otherwise, S. leucanthemoides is only known from the type locality 


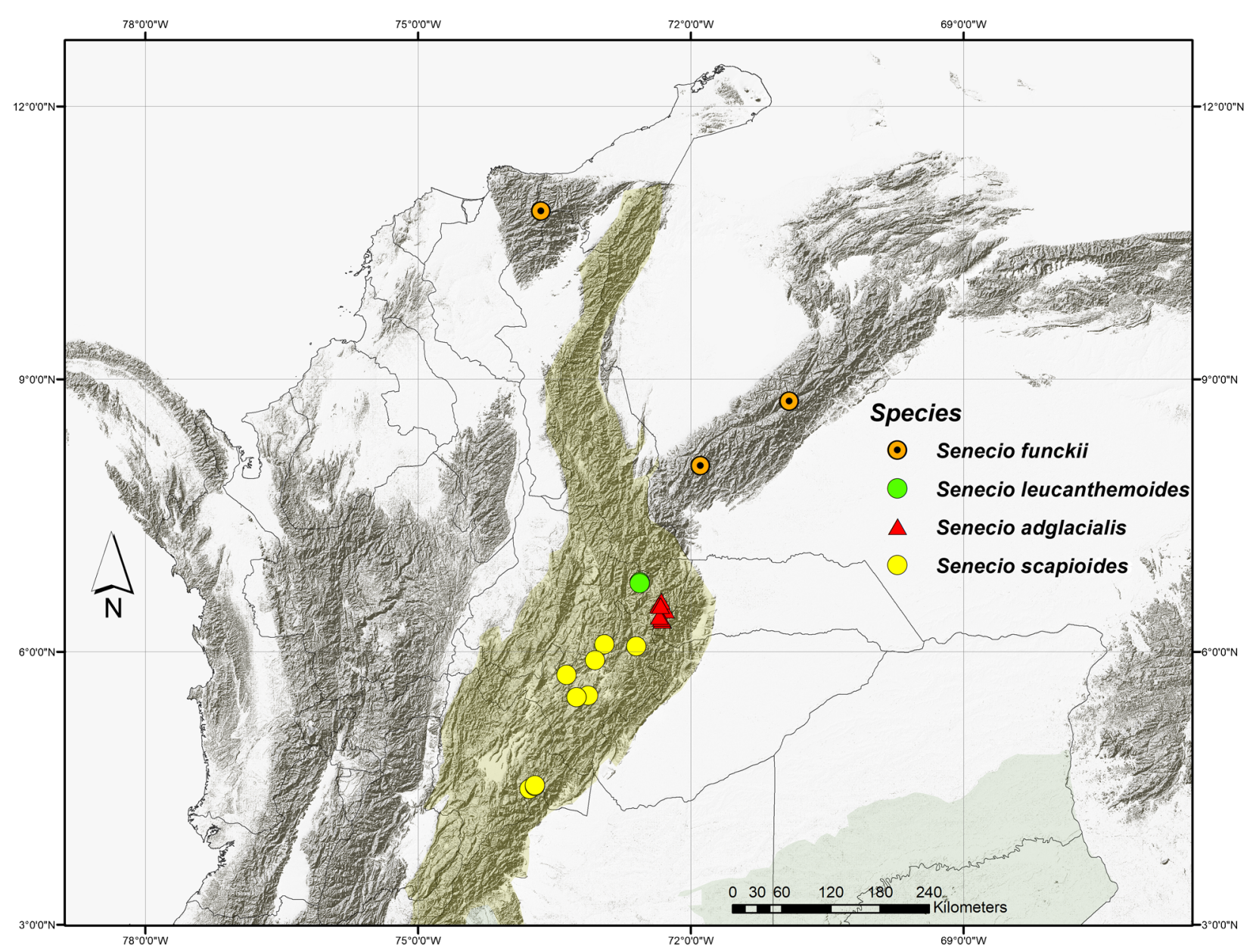

Map 1. Geographical distribution of Senecio scapioides and similar species: S. adglacialis, S. leucanthemoides and S. funckii.

in the páramo of Almorzadero (Departamento de Santander) (Map 1), a humid shrubby páramo at $3800 \mathrm{~m}$ elevation, and represents the northernmost distribution for this group of rhizomatous, scapiform species with yellow radiate capitula. A table of comparison of selected characters amongst Senecio scapioides and these closest relatives is provided in Table 1 .

The radiate capitula with the two types of yellow floret noted in the new species also resembles Senecio funckii, a species restricted to two disjunct localities in the Venezuelan Sierra Nevada de Merida and in the Colombian Sierra Nevada de Santa Marta (Ávila et al. in Bernal et al. 2015; Hokche et al. 2008) (Map 1). Nevertheless, the indumentum, habit and leaf type of $S$. funckii are distinctly different, being glabrate, suffrutescent with erect branches, no rhizome, an inflorescence leafy throughout, with flat leaves possessing doubly dentate margins, while S. scapioides and its morphological and geographical relatives, are perennial herbs with a basal rhizomatous stem, their basal leaves rosettiform, the inflorescences scapiform and the leaf margins always revolute, crenate, and completely covered with an arachnoid and sericeous indumentum (Fig. 1A; 2A, B; 3B, C).

\section{Acknowledgements}

This study was conducted under the memorandum of Collaboration between Instituto Humboldt and RBG Kew, "Building a Partnership of Systematic Excellence" supported by the Boyacá Bio programme and Newton fund (via BEIS = Department for Business, Energy \& Industrial Strategy, UK). The authors would like to thank Gustavo Surlo, the Margaret Mee Fellowship Programme Artist Scholar 2018, and the $24^{\text {th }}$ such scholar, for providing the black and white line drawings of this new species. Grateful thanks is also given to two anonymous reviewers whose comments have helped improve the original submission.

Open Access This article is licensed under a Creative Commons Attribution 4.0 International License, which permits use, sharing, adaptation, distribution and reproduction in any medium or format, as long as you give appropriate credit to the original author(s) and the source, provide a link to the Creative Commons licence, and indicate if changes were made. The images or other third party material in this article are included in the article's Creative Commons 
licence, unless indicated otherwise in a credit line to the material. If material is not included in the article's Creative Commons licence and your intended use is not permitted by statutory regulation or exceeds the permitted use, you will need to obtain permission directly from the copyright holder. To view a copy of this licence, visit http://creativecommons.org/ licenses/by/4.0/.

\section{References}

Avila, F., Funk, V. A., Diazgranados, M., DíazPiedrahíta, S. \& Vargas, O. (contribs.). (2016). Asteraceae. In: R. Bernal, S. R. Gradstein \& M. Celis (eds), Catálogo de plantas y líquenes de Colombia. Vol. I. Capítulos introductorios - Líquenes a Lythraceae, pp. 795 - 908. Instituto de Ciencias Naturales, Facultad de Ciencias, Sede Bogotá, Universidad Nacional de Colombia.

Bernal, R., Gradstein, S. R. \& Celis, M. (2015). Catálogo de plantas y líquenes de Colombia. Instituto de Ciencias Naturales, Universidad Nacional de Colombia, Bogotá. Available from: http:// catalogoplantasdecolombia.unal.edu.co. (Data base accessed from 15 August 2016).

\& __ (eds) (2016a). Catálogo de plantas y líquenes de Colombia. Vol. I: Capítulos introductorios Líquenes a Lythraceae. Instituto de Ciencias Naturales, Facultad de Ciencias, Sede Bogotá, Universidad Nacional de Colombia.

\&___ (eds) (2016b). Catálogo de plantas y

liquenes de Colombia. Vol. II: Magnoliaceae a Zygophyllaceae - Éspecies introducidas y cultivadas. Instituto de Ciencias Naturales, Facultad de Ciencias, Sede Bogotá, Universidad Nacional de Colombia.

Cleef, A. M. (1981). The vegetation of the páramos of the Colombian Cordillera Oriental. Diss. Bot. 61: 1 320. Cramer, Vaduz.

Colombia BIO (2016). Colombia BIO. https:// www.colciencias.gov.co/portafolio/colombia-bio. Site accessed 26 Dec. 2018 [Downloadable PDF resenacolombibio-2016 explains the programme, in Spanish.]

Hind, D. J. N. (2011). An annotated preliminary checklist of the Compositae of Bolivia. Vers. 2. [See www.kew.org/science/tropamerica/boliviacompositae for the web version and www.kew.org/science/tropamerica/ boliviacompositae/checklist.pdf for the PDF file of the checklist].

Hokche, O., Berry, P. E. \& Huber, O. (2008). In: O. Hokche, P. E. Berry \& O. Huber (eds), Nuevo Catálogo de la Flora Vascular de Venezuela. Dicotiledoneas, pp. 185 - 352. Fundación Instituto Botánico de Venezuela, Caracas.

IPCC (2014). R. K. Pachauri \& L. A. Meyer (eds), Climate Change (2014). Synthesis Report. Contribution of Working Groups I, II and III to the Fifth Assessment Report of the Intergovernmental Panel on Climate Change. IPCC, Geneva.

IUCN Standards and Petitions Subcommittee (2013). Guidelines for using the IUCN Red List Categories and Criteria. Version 10.1. Prepared by the Standards and Petitions Subcommittee. Available from: http:// www.iucnredlist.org/documents/RedListGuidelines. pdf (accessed 25 August 2018).

Miranda-Esquivel, D., Rangel, J. \& Roa, L. (2002). Endemismo en páramos colombianos con base en la distribución de espermatófitos y el análisis de parsimonia de endemismo (PAE). In: C. AngeJaramillo, C. Castaño-Uribe \& C. L. Durán, Memorias del Congreso Mundial de Páramos 1: 253 266. Ministerio del Ambiente, Bogotá.

Moreno, L. A., Andrade, G. I. \& Ruíz-Contreras, L. F. (eds) (2016). Biodiversity 2016. Status and Trends of Colombian Continental Biodiversity. Research Institute of Biological Resources Alexander von Humboldt, Bogotá.

Nordenstam, B., Pelser, P. B., Kadereit, J. W. \& Watson, L. E. (2009). Senecioneae. In: V. A. Funk, A. Susanna, T. F. Stuessy \& R. J. Bayer (eds), Systematics, Evolution, and Biogeography of Compositae, pp. 503 - 525. International Association for Plant Taxonomy, Vienna.

Vásquez, D. L. A., Balslev, H. \& Sklenář, P. (2015). Human impact on tropical-alpine plant diversity in the northern Andes. Biodivers. E Conservation 24: $2673-2683$.

\section{Publisher's Note}

Springer Nature remains neutral with regard to jurisdictional claims in published maps and institutional affiliations. 